\title{
The Nibbler Girella leonina and the Soldierfish Myripristis murdjan from Midway Atoll, First Records for the Hawaiian Islands ${ }^{1}$
}

\author{
Fobn E. Randall ${ }^{2}$ and G. Keoki Stender ${ }^{3}$
}

\begin{abstract}
The girellid fish Girella leonina (Richardson) and the holocentrid Myripristis murdjan (Forsskall) are reported for the first time for the Hawaiian Islands from underwater photographs taken at Midway Atoll. Both species can be positively identified by the photographs.
\end{abstract}

Midway Atoll, near the northwestern end of the Hawaiian Islands at $28^{\circ} 15^{\prime} \mathrm{N}, 177^{\circ} 23^{\prime}$ $\mathrm{W}$, has a fish fauna with some noteworthy differences from that of the main islands of the archipelago, Hawai'i to Kaua'i at $19-22^{\circ}$ N (Randall et al. 1993b). There are fewer species of shore fishes, but some of the ones that are known from deeper than scubadiving depths in the main islands, such as the grouper Epinephelus quernus, the angelfish Genicanthus personatus, and the goatfish Parupeneus chrysonemus, are often seen while diving in the cooler seas of Midway. Still others are abundant at Midway but rare in the main islands. And a few at Midway, such as the angelfish Centropyge interrupta and the two knifejaws of the genus Oplegnathus, are known from Japan but are absent or exceedingly rare in the main islands.

In his role of manager of Midway Sport Diving for two years commencing April 1999, G.K.S. had the opportunity to look for species of fishes that have not been previously recorded from the atoll. Among several he has discovered are two that are new records for all of the Hawaiian Islands as well as Midway.

The fish fauna of the Hawaiian Islands has the highest level of endemic shore fishes of any locality of the Indo-Pacific region: $23.1 \%$

\footnotetext{
${ }^{1}$ Manuscript accepted 11 July 2001.

${ }^{2}$ Bishop Museum, 1525 Bernice Street, Honolulu, Hawai'i 96817-2704.

33 41-652 Inoaole Street, Waimānalo, Hawai'i 96795.
}

Pacific Science (2002), vol. 56, no. 2:137-141

(C) 2002 by University of Hawai'i Press.

All rights reserved
(Randall 1998). When first determined by Gosline and Brock (1960), the percentage of endemic fishes was $34 \%$. This has steadily diminished as presumed Hawaiian endemics turned up at other localities and as new records of fishes extralimital to Hawai'i have been recorded. Many of these recent arrivals are waifs that have drifted in as larvae, transformed to juveniles, and survived to the moment they were collected. The vast majority of the larval fishes that drift into Hawaiian waters from distant localities never establish the species because they fail to find others of their kind for spawning or because something about the environment is different enough from their home area to preclude reproduction. An example of the latter is the attempted introduction of 469 dwarf spotted groupers (Epinephelus merra) from Moorea in the Society Islands to Kāne'ohe Bay, O'ahu, and 132 that were released off Wainini, Kaua'i, in 1956 (Randall 1960). Their release in Kāne'ohe Bay was a proper choice in terms of habitat because the species occurs primarily in lagoons. The introduced adults lived out their lives, but no young ever appeared. Although the sea temperature at $\mathrm{O}^{\prime}$ ahu and Kaua' $i$ is a little cooler than at Moorea, this grouper occurs in Rapa, the southernmost island of French Polynesia, and in southern Japan where the sea is cooler than in the Hawaiian Islands. Therefore, some unknown factor or factors other than temperature prevented their becoming established in Hawaiian waters (which was fortunate because the species was not a good choice for introduction due to its small size).

The purpose of this paper is to report two species new to the Hawaiian Islands based on photographs taken at Midway Atoll. One is a 
species of Girella (family Girellidae) that may be only a stray from its normal range of Japan, Taiwan, and China, whereas the other, a species of Myripristis (family Holocentridae), is wide-ranging in the Indo-Pacific region and is common enough at Midway to indicate that it is represented by a breeding population.

Girella leonina Richardson, 1846

Figure 1

An individual of the genus Girella was first observed by G.K.S. at the atoll near Frigate Point, Sand Island, in July 1999. In September we observed two subadults of about $16 \mathrm{~cm}$ total length under the cargo pier at Sand Island (one of these was believed to be the same as the first fish that was observed). The two fish were difficult to approach, but we both took photographs. No attempt was made to collect a specimen because Midway is a National Wildlife Refuge.

A juvenile was seen in the lagoon in April 2000 by G.K.S., and three adults of about 35 $\mathrm{cm}$ were observed at Frigate Point where the depth was $15 \mathrm{~m}$. They were unusual in being high in the water column. A subadult of about $20 \mathrm{~cm}$ was photographed (Figure 1) in May 2000 in $6 \mathrm{~m}$ along the reef front near the western end of the barrier reef. The site was visited weekly throughout the summer, but the fish was not seen again.

As noted by Yagishita and Nakabo (2000) in their review of the three East Asian species of Girella, the genus is antitropical in temperate and subtropical waters. It is represented by about 14 species in the Indian and Pacific Oceans, and by one in the eastern At-

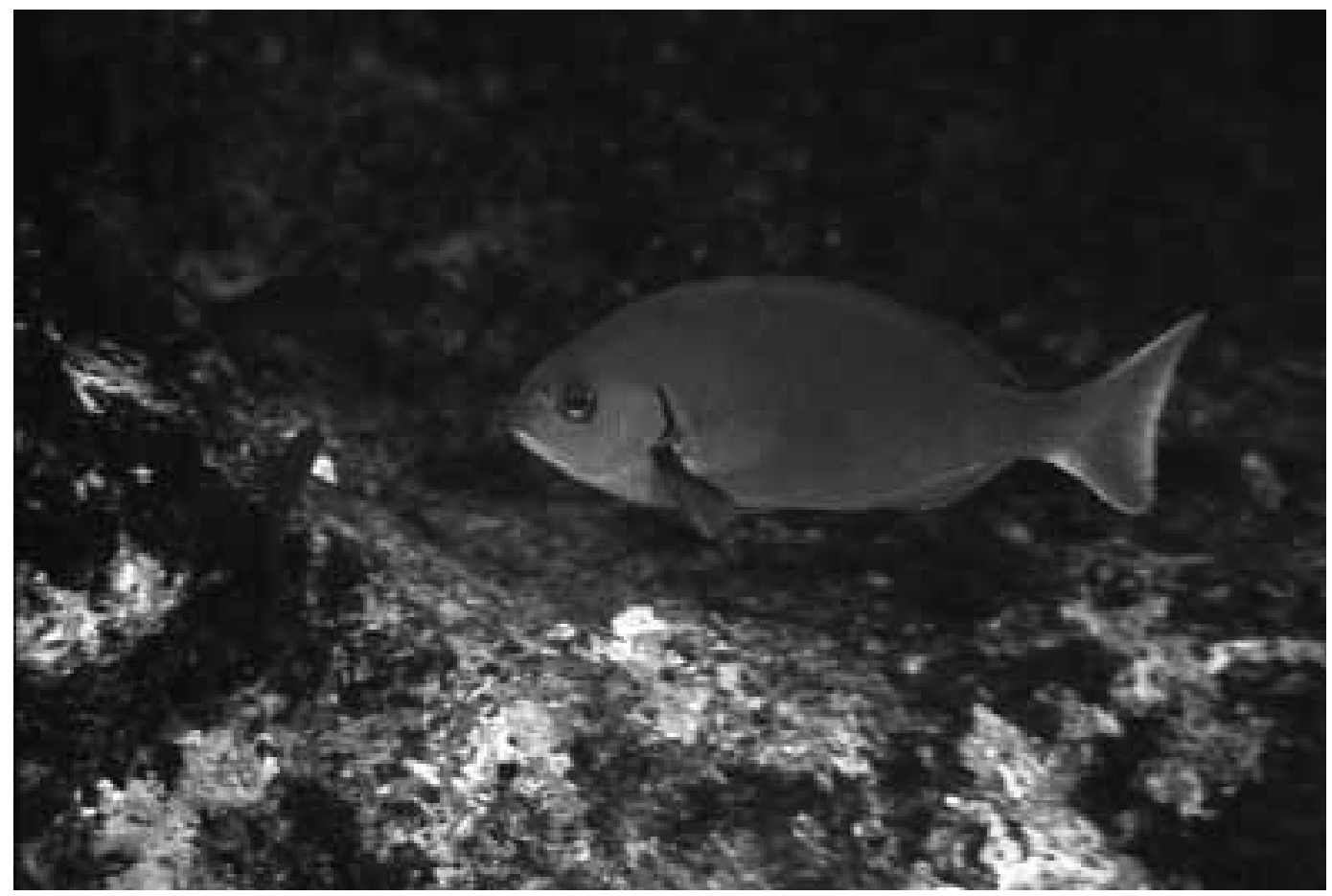

Figure 1. Girella leonina, about $20 \mathrm{~cm}$ total length, Midway Atoll, outside barrier reef near western end (G. K. Stender). 
lantic. They classified the genus in the family Girellidae, but some authors have preferred to place it as a subfamily within the Kyphosidae.

We initially identified the Midway fish as Girella melanichthys (Richardson, 1846), using such recent references as Masuda et al. (1984:166, pl. 151 G) and Okamura and Amaoka (1997:414, upper and middle left figures); however, Yagishita and Nakabo (2000) have shown that G. melanichthys is a synonym of $G$. punctata Gray, and the species we identified as $G$. melanichthys is $G$. leonina, also described by Richardson (1846). Jordan and Thompson (1912), the first to misidentify Girella punctata as G. melanichthys, were followed by many authors.

Girella leonina can be identified without the collection of a specimen by the black color of its exposed opercular membrane (Yagishita and Nakabo 2000). It occurs from Boso Peninsula in central Honshu south to Taiwan and the coast of China at least to Hong Kong. The largest of 220 specimens examined by Yagishita and Nakabo measured $46 \mathrm{~cm}$ standard length (hence about $57 \mathrm{~cm}$ total length). Araga in Masuda et al. (1984) wrote that it is the largest species of the genus, attaining 70 $\mathrm{cm}$ total length. It ranges farther south, and is found in more exposed coastal areas than $G$. punctata.

With a total of only seven individuals of Girella leonina observed in $2 \mathrm{yr}$, the species may not be represented by a breeding population at Midway; these fish may be waifs that drifted in as larvae from a locality such as Japan. The spadefish Platax boersii and the puffer Arothron manilensis are examples of waifs to the Hawaiian Islands from a probable western Pacific origin such as southern Japan (Randall et al. 1993a).

Some colorful species that are common in the aquarium trade have turned up occasionally in Hawaiian waters that are probable aquarium releases. Because of this, we cannot regard the discovery of such individuals as valid records. We can be confident, however, that Girella leonina at Midway is naturally occurring because the species is too drab and reaches too large a size to be considered for a home aquarium.

\section{Myripristis murdjan (Forsskål, 1775)} Figure 2

A species of Myripristis at Midway Atoll was often seen by G.K.S. that he could not identify from literature on the Hawaiian fish fauna. He sent an underwater photograph to J.E.R. It was sharp enough so that a count could be made of the lateral-line scales as 28 or 29. This would eliminate all the known species of Myripristis in the Hawaiian Islands except M. berndti Jordan \& Evermann (Randall and Greenfield 1996: table 2).

It was then suggested that more photographs be taken so that enough of the spinous portion of the dorsal could be seen to determine its color. The outer part of the spinous dorsal of Myripristis berndti is broadly bright orange-yellow. G.K.S. succeeded in taking such a photograph (Figure 2), revealing the spinous part of the fin as bright red distally. His photograph also shows the mouth as nearly terminal, in contrast to that of adult M. berndti, which has a strongly jutting lower jaw. Furthermore, there is no blackish bar through the eye that is characteristic of $M$. berndti.

The characters that eliminated Myripristis berndti favor M. murdjan (Forsskål), which is wide-ranging from the Red Sea (type locality) and coast of East Africa to the Marshall Islands and American Samoa. It occurs in the western Pacific from the Ryukyu Islands and Taiwan to the southern Great Barrier Reef. It has no value as an aquarium fish because it is a nocturnal feeder on zooplankton.

Only one other species of the genus Myripristis with a modal lateral-line scale count of 28 or 29 is a possibility for the Midway fish: M. kochiensis Randall \& Yamakawa, known only from Japan. It can also be eliminated because of having an orange-yellow outer part of the spinous portion of the dorsal fin and a dark bar through the eye.

Unlike Girella leonina, Myripristis murdjan is not rare at Midway, and it has also been observed by G.K.S. at Kure Atoll to the west of Midway. It was usually seen along the southwestern barrier reef of Midway in large caves at depths of 10-20 m. In most cases about one to three individuals accompanied 


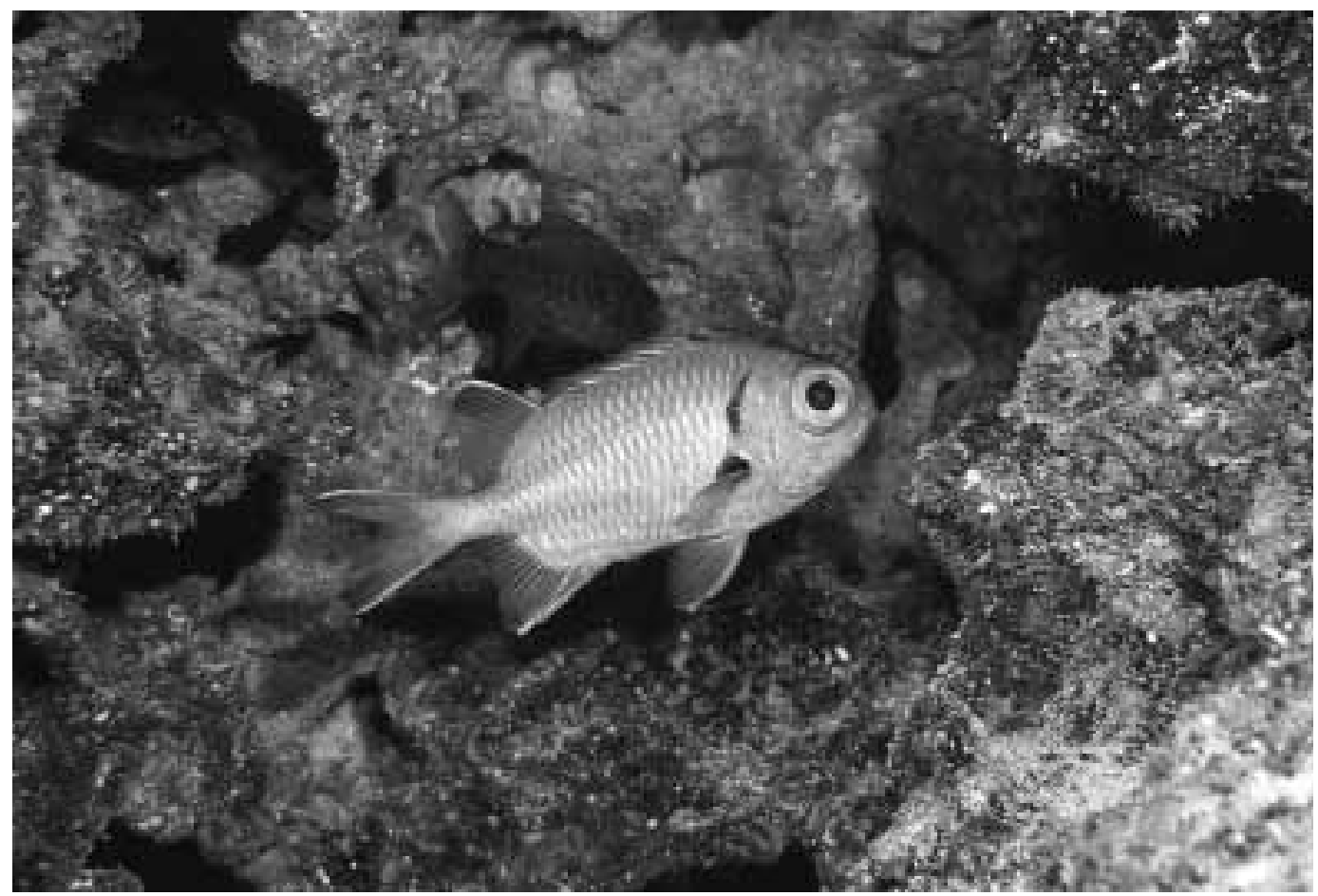

Figure 2. Myripristis murdjan, about $20 \mathrm{~cm}$ total length, Midway Atoll, outside barrier reef at southwestern corner of atoll (G. K. Stender).

aggregations of $M$. berndti that could number as many as about 75 individuals. The $M$. murdjan were more shy and usually retreated to the back of the cave rather than remaining with the milling M. berndti.

\section{Literature Cited}

Forsskål, P. 1775. Descriptiones animalium, avium, amphibiorum, piscium, insectorum, vermium; quae in itinere orientali observait. Mölleri, Copenhagen.

Gosline, W. A., and V. E. Brock. 1960. Handbook of Hawaiian fishes. University of Hawai'i Press, Honolulu.

Jordan, D. S., and J. W. Thompson. 1912. Record of the fishes obtained in Japan in 1911. Proc. U. S. Natl. Mus. 41:521601.
Masuda, H., K. Amaoka, C. Araga, T. Uyeno, and T. Yoshino, eds. 1984. The fishes of the Japanese Archipelago. Tokai University Press, Tokyo.

Okamura, O., and K. Amaoka. 1997. Sea fishes of Japan. Yama-Kei Publishers, Tokyo (in Japanese).

Randall, J. E. 1960. New fishes for Hawaii. Sea Frontiers 6 (1): 33-43. . 1998. Zoogeography of shore fishes of the Indo-Pacific region. Zool. Stud. 37 (4): 227-268.

Randall, J. E., and D. W. Greenfield. 1996. Revision of the Indo-Pacific holocentrid fishes of the genus Myripristis, with descriptions of three new species. Indo-Pac. Fishes, no. 25: 1-61.

Randall, J. E., J. L. Earle, T. Hayes, C. Pittman, M. Severns, and R. J. F. Smith. $1993 a$. Eleven new records and validations 
of shore fishes from the Hawaiian Islands. Richardson, J. 1846. Report on the ichthyolPac. Sci. 47:222-239.

Randall, J. E., J. L. Earle, R. L. Pyle, J. D. Parrish, and T. Hayes. 1993b. Annotated checklist of the fishes of Midway Atoll, Northwestern Hawaiian Islands. Pac. Sci. $47: 356-400$. ogy of the seas of China and Japan. Rep. Br. Assoc. Adv. Sci. (1845): 187-320.

Yagishita, N., and T. Nakabo. 2000. Revision of the genus Girella (Girellidae) from East Asia. Ichthyol. Res. 47 (2): 119-135. 